\title{
THE RIGHT TO A FAIR TRIAL: THE ROLE OF THE TRANSLATOR- INTERPRETER IN THE CRIMINAL TRIAL
}

\author{
D. D. Dănişor
}

\author{
Diana-Domnica Dănişor \\ Faculty of Law and Administrative Sciences, \\ University of Craiova, Craiova, Romania \\ *Correspondence: Diana-Domnica Dănişor, University of Craiova, 13 Al. I. Cuza Street, \\ Craiova, 200585, Dolj, Romania \\ E-mail: danisordiana@yahoo.ro
}

\section{Abstract}

The judicial dialogue, as an expression of judicial controversy, is organized in the national language. In order to observe the principle of audi alteram partem, when a litigant speaking another language is present, it is required that the dialogue should be reconstituted with the assistance of a translator-interpreter. The latter informs the litigant who speaks another language of "all acts that may affect him to a certain extent", in order to make the counsel understand the proceedings and to protect the rights of the person he defends. The translator-interpreter is thus the protector of the rights of the person for whom he translates, allowing the accused to participate in the debate. The presence of this occasional collaborator is a guarantee of good justice. Standing among the actors of a trial, the interpreter is the faithful transmitter of each person's words by the search of equivalences between two utterances. The translation must render as accurately as possible the intentions of the author of the translated utterance, thus becoming an "accurate re-creation", a "creation of meaning". Frequently based on "syntactical archaisms" and "stereotyped formulas", these turns do not have an equivalent in other languages.

Keywords: the right to a fair trial, Romanian Constitution, the judicial dialogue, New Code of Criminal Procedure.

Section 1. The right to a fair trial in the Romanian Constitution and in the European Convention on Human Rights

The right to a fair trial is safeguarded by the Romanian Constitution in art. 21(3), stipulating that "All parties shall be entitled to a fair trial and a decision in their cases within a reasonable time". As for the language in which the trial is conducted, the Constitution provides, in art. 128, Use of mother tongue and interpreter in court: "(1) The legal procedure shall be conducted in Romanian. (2) Romanian citizens belonging to national minorities shall have the right to use their mother tongue before the courts of law, under the terms of the organic law. (3) The ways of exercising the right stipulated in paragraph (2), including the use of interpreters or translations, shall be stipulated so as not to prevent proper administration of justice and not to involve additional expenses for those interested. (4) Foreign citizens and stateless persons who do not understand or do not speak the Romanian language shall be entitled to be informed of all the documents and materials in the file, to speak in court and draw conclusions, by means of an interpreter; in criminal trials, this right is ensured free of charge". The judicial dialogue, as an expression of judicial controversy ${ }^{1}$, is organized in the national language. In order to observe the principle of audi alteram partem, when a litigant

\footnotetext{
1 "La procédure c'est l'organisation de la controverse", Wierderkehr, G., Droits de la défense et procédure civile, D 1978, Chron, p. 38.
} 
speaking another language is present, it is required that the dialogue should be reconstituted with the assistance of a translator-interpreter. The latter informs the litigant who speaks another language of "all acts that may affect him to a certain extent" ${ }^{2}$, in order to make the counsel understand the proceedings and to protect the rights of the person he defends. The translator-interpreter is thus the protector of the rights of the person for whom he translates, allowing the accused to participate in the debate. "The presence of this occasional collaborator is a guarantee of good justice" 3 . So as to ensure the accuracy of information, the intervention of this third party, acting like an agent between the judge and the litigant, becomes ineluctable.

Stated in the European Convention on Human Rights and Fundamental Freedoms, the "fair trial" includes equal rights of speech whatever the language of the lawyer. A genuine dialogue cannot exist without understanding the debates. Even if the judge, litigant and lawyer speak the same language, they do not necessarily understand each other, and so much the more, they cannot communicate without recourse to a third party as a translator when they speak different languages. In accordance with art. 6(3) of the European Convention on Human Rights, "Everyone charged with a criminal offence has the following minimum rights: (a) to be informed promptly, in a language which he understands and in detail, of the nature and cause of the accusation against him; (e) to have the free assistance of an interpreter if he cannot understand or speak the language used in court".

\section{Section 2. Appointing an interpreter}

In order to permit the effective participation of the accused in the debate, it is essential to appoint an interpreter. In criminal matters, the assistance of a translator restores the balance between actors, allowing the accused to be heard in person. But in case the presence of the defendant in the debate is essential, there is a law protecting his interests, freedom and speech. The presence of an interpreter is regulated in the New Code of Criminal Procedure ${ }^{4}$, which, under art. 11, Official language and the right to an interpreter provides: "(1) The official language in the criminal trial is Romanian. (2) Romanian citizens belonging to national minorities shall have the right to use their mother tongue before the courts of law, the procedural acts being drafted in Romanian. (3) All parties involved in the criminal trial who do not speak or understand the Romanian language or cannot express themselves shall be entitled, free of charge, to be informed of the documents in the file, to speak and draw conclusions before the court, by means of an interpreter. (4) Certified interpreters shall be used during judicial proceedings, as provided by law. The category of interpreters also includes certified translators, as provided by law". The legal classification of the activity of translation and the profession of translator is provided by INSEE Order no. 273/2002 $2^{5}$ within the group called "Specialists with intellectual and scientific occupations", position "Linguists,

\footnotetext{
2 "The right to information precedes the exercise of the right of defence, the effect of surprise being proscribed in an absolute manner. The judicial law requires that the litigant should be precisely informed of all acts that may affect him to a certain extent", Salah-Bey, M., "Les droits de la défense liés à l'information dans le proces civil", in L'information en droit privé, LGDJ, 1978, p. 73.

${ }^{3}$ Eschylle, J.-F., L'interprétation en matière pénale, RSC, 1992, p. 261.

${ }^{4}$ The previous Code of Criminal Procedure provided under art. 7: "In the criminal trial the judicial proceedings shall be conducted in the Romanian language, the parties and other persons summoned in court shall be entitled to use their mother tongue before the judicial bodies, the procedural acts being drafted in Romanian". Art. 8 mentioned the use of the official language by means of an interpreter: "The parties who do not speak or understand the the Romanian language or cannot express themselves shall be entitled, free of charge, to be informed of the documents in the file, to speak and draw conclusions before the court, by means of an interpreter".

${ }^{5}$ Regarding the approval of the Procedure for bringing up to date the classified list, The classification of occupations in Romania.
} 
translators and interpreters". The activity of certified translators is regulated by Law no. $178 / 1997^{6}$ and the Regulation for the enforcement of this law ${ }^{7}$.

The principle of oral debates before the court, that of being heard in person "to the extent that the focus will be on examining the personality of the defendant" justifies the systematic use of an interpreter during the hearing ${ }^{8}$. The interpreter must be morally competent, since he transmits, without any possibility of being controlled, what the parties say during the trial, the judges and clerks to the courts not being able to know all languages? Etymologically, the term interpreter comes from inter partes, the interpreter finding himself between two persons who could not understand each other or communicate without his assistance. Or from inter praes, the guarantor between two persons who cannot understand each other, or between either of them and another person. Actually, the 'unfaithful' interpreter is subject to the risk of sanctions under criminal law or civil law, or disciplinary sanctions.

The presence of the interpreter makes the counsel benefit from protection consisting in the certitude to express himself and the possibility of understanding what the magistrates say. The mere assistance during the oral debates is not sufficient, the communication of procedural acts drafted in Romanian or of documents written in a foreign language requiring the intervention of the translator-interpreter for the translation of the documents in the file. Therefore, the appointment of an interpreter is a right of the person charged with a criminal offence. The omission of the prosecution to ensure, free of charge, the use of an interpreter, in the cases provided under art. 128 of the Code of Criminal Procedure involve the relative nullity of the acts performed during the prosecution, under art. 197(1) and (4) of the same code. Consequently, the violation of art. 128 may be raised during the completion of the act if the party is present, or at the first hearing with the observance of the procedure if the party was absent when completing the act; it is too late to mention the party for the first time on appeal.

\section{Subsection 1. The double mission of the interpreter: to assist during oral debates and to translate documents}

The essential mission of the interpreter is to translate for the defendant what was said during the hearing and to assist him in communicating his own statements. The interpreter must translate all that is useful for the perfect understanding of the debates, so that the defendant will understand, when he is addressed, the testimonies of the witnesses, the questioning of co-defendants, the documents read out during the hearing and, in particular, the written statements of the witnesses, the bill of indictment of the Public Ministry, the content of the sentence.

The translation of written documents raises two kinds of difficulties: on the one hand, the procedural acts drafted in Romanian must be translated for the defendant into his own language and, on the other hand, the documents written in a foreign language and presented by the counsel must be understood by the judge and the other parties. In Philippe Malaurie's opinion, "certain decisions involve, indeed, the fact that the judge has the ability to translate ex officio" the documents presented before the court in a foreign language, because the judge has today "the power to invoke ex officio the foreign law, so much the more one must recognize his ability to translate, ex officio, a foreign document on condition that the rights of the defendant should be observed, or to require its translation for the reopening of the

\footnotetext{
${ }^{6}$ For the authorisation and payment of interpreters and translators used by the Superior Council of Magistracy, the Ministry of Justice, the Prosecutor's Office within the High Court of Cassation and Justice, the National Anticorruption Prosecutor's Office, prosecution bodies, courts, offices of notaries public, lawyers and bailiffs.

${ }^{7}$ Regulation for the enforcement of Law no. 178/1997 as approved by Order of the Minister of Justice no. $1054 / \mathrm{C} / 2005$.

${ }^{8}$ Lasalle, J.-Y., La comparution du prévenu, RSC 1981, p. 541.

${ }^{9}$ Merlin, Répertoire universel et raisonné de jurisprudence, Tom. XV, ed. 5, Bruxelles, 1826, p. 485.
} 
debates"10. The European Court of Human Rights states that the right to an interpreter is not confined to interpretation, it also extends to the translation ... of all procedural acts against the defendant that he has to understand in order to have a fair trial ${ }^{11}$. Starting from art. 6 of the European Convention on Human Rights and Fundamental Freedoms, the Court finds the principle of equal footing absolutely necessary for a fair trial. This equal footing can only be fulfilled if the facilities granted to a counsel who knows the language of the judge, in order to prepare the case, are identical with those of the defendant who ignores this language. The trial is governed by a great principle: that of the "fair trial"12 lying at the basis of the obligation to inform the defendant who speaks a foreign language in his own language, for the purpose of protecting human rights, since "the right to a fair trial stands among the fundamental requirements of a human being"13. Therefore the idea of a fair trial should include the protection of the defendant who speaks a foreign language from the very moment of his arrest until the verdict is given.

\section{Subsection 2. The interpreter, an agent for the creation of an imperfect dialogue between the actors of the criminal trial}

The intervention of an interpreter creates a risk of distorting what the magistrate and litigant say, because "translation is always betrayal"14, it is never complete ${ }^{15}$. Translation must be "as neutral as possible, as simply transparent as possible between two identical discourses ${ }^{16}$. Exceeding the simple juxtaposition of terms, translation is rarely a calque, its main objective remaining the acceptance of the decision by the counsel speaking a foreign language, since "there is no legitimacy for the judge unless he makes himself understood"17.

The European Court of Human Rights sets a limit to the scope of the right to be informed in one's own language. It holds "a concatenation of equivalences which, in fact, are not: the right of the defendant to speak $=$ the right to defend oneself $=$ the right of defence $=$ prerogatives of the lawyer representing the defendant when he is, normally, present" ${ }^{\text {"18 }}$.The litigant is informed by means of translation of the essential acts involving the protection of the defence rights, but he is not completely informed of the proceedings in his own trial, which leads to a vague understanding of procedural acts. In criminal matters, this limitation of the domain in which the translator intervenes is compensated by the assistance, free of charge, of an interpreter, thus maintaining the balance between litigants by eliminating the pecuniary difficulty which might deprive the defendant of the translator's help. To be effective, the assistance of an interpreter must be free of charge. The restoration of equal footing and equal access to justice involves this exemption from payment ${ }^{19}$. Stipulated under criminal law, it does not exist in other proceedings. Confined to ensuring oral interpretation, it is debatable for the translation of documents, even if the understanding of the trial by the litigant involves this

\footnotetext{
${ }^{10}$ Malaurie, Ph., Le droit français et la diversité des langues, Journal de droit international, 1965, p. 583.

${ }^{11}$ Cour européenne des droits de l'homme, Affaire Luedicke, Belkacem et Koç, 28 November 1978, series A, no. $29 \& 48$.

${ }^{12}$ Koering-Joulin, R., La notion européenne de „tribunal indépendant et impartial” au sens de l'article 6 de la Convention européenne de sauvegarde des droits de l'homme, RSC 1990, p. 765.

${ }^{13}$ Sperduti, G., L'article 6 de la Convention européenne des Droits de l'Homme et les décisions administratives internes affectant des droits de caractère civil, Mélanges Pictet, 1984, p. 813.

14 "Déjà la langue ordinaire n'est jamais traduisible à 100\% mais la langue juridique, qui plus est, est différente les difficulté seront ainsi multipliées".

${ }^{15}$ Mauro, J., Au Carrefour des droits et des langues: La langue applicable au contrat, le risqué linguistique, Gaz Pal 1988/1, Doctr. P. 214.

${ }^{16}$ Didier, E., Langues et langage du droit, Wilson / Lafleur Ltée, Montréal, 1990, p. 241.

${ }^{17}$ Madame Burdeau, A synopsis of the colloquium "Justice sans frontières, le juge et l'étranger", Gaz Pal 3-4 February 1993, nos. 34-35, p. 47.

${ }^{18}$ Soulier, G., L'égalité de parole, principe de la démocratie et du procès pénal, Le théâtre et le procès, nos. 17$18 / 1991$, p. 8.

${ }^{19}$ The European Court of Human Rights stated the importance of judicial assistance as a means for ensuring the effective right of access to justice, see especially Affaire Airey, 9 October 1979, series A, no. 32.
} 
extension. The exemption from payment for the assistance of an interpreter, introduced in the European Convention on Human Rights and in Resolution (75)3 on the legal and administrative aspects of criminality among migrant workers, ensures its full intensity to linguistic assistance.

\section{Conclusions}

Translation, an inaccurate information instrument. Equivalence in translation is often uncertain $^{20}$, just as misunderstanding is part of any communication through language, for "faithfulness towards meaning is a search, not a prior certitude" ". The interpreter, as an agent between the judge and the litigant, reconstructs the message and ensures a minimum understanding between interlocutors. In this respect, the interpreter may find the literal meaning or may move away from mere translation, in the latter case remaining faithful to terms or their meaning. Meant to be faithful to the meaning of the message, the mission of the interpreter is also that of reconstructing the meaning of the utterance according to the abilities of the addressee, or the legal system where he intervenes. For the judge, the presence of the interpreter is essential, due to the fact that the latter transmits necessary information for deciding in the case. The translator does not have too much time to add the necessary explanations for the understanding of cultural and system differences. "Not simultaneous interpretation, but consecutive and synthetic interpretation" is admitted ${ }^{22}$. Standing among the actors of a trial, the interpreter is the faithful transmitter of each person's words by the search of equivalences between two utterances. The translation must render as accurately as possible the intentions of the author of the translated utterance, thus becoming an "accurate recreation", a "creation of meaning" 23 . Frequently based on "syntactical archaisms" and "stereotyped formulas", these turns do not have an equivalent in other languages. Since they cannot be translated word by word, so as not to miss the significance or not to modify it, these expressions must be known by the translator for the re-creation of meaning ${ }^{24}$. The interpreter ignores the nature of the litigation and does not necessarily have legal knowledge; therefore he reconstructs the message according to his own perception of the trial. For complex utterances, he must understand the litigation and know the procedure well enough and, better, have legal knowledge. The interpreter's competence most often resolves linguistic disparity ${ }^{25}$. The linguistic barrier appears as a barrier between cultures, the interpreter having an explanatory, creative mission with regard to the original message, transmitting a simplified message reflecting, by translating what the magistrate says, the culture and terminology which might be familiar to the litigant. When translating, there is a "transfer of concepts, the expression of the intellectual lives of two peoples. It does not mean finding or explaining reality, but assimilating a civilisation" 26 . And the other way round, an interpreter may explain to a magistrate who does not understand, certain expressions of the litigant speaking another language, by a multicultural approach.

\section{Bibliography}

\footnotetext{
${ }^{20}$ For an analysis of translation difficulties in international law, see Lazăr Focşăneanu, Les langues comme moyen d'expression en droit international, AFDI, 1970, p. 256.

${ }^{21}$ Pergnier, M., Les fondements sociolinguistiques de la traduction, Thesis, Lib. Honoré Champion, 1978, p. 2527.

${ }^{22}$ Affaire Kamasinski, 19 December 1989, p. 31.

${ }^{23}$ Michaud, J., Le traducteur et l'expert, RSC 1985, p. 267.

${ }^{24}$ Terré, Fr., Brèves notes sur les problèmes de la traduction juridique, Revue internationale de droit comparé, 1986 , p. 350.

${ }^{25}$ Michaud, J., Traducteur-interprète-expert, Textes et réalités, Gaz. Pal. 21-23 March 1993, Doctr., p. 3.

${ }^{26}$ Kahn, Ph., note sous Com. 25 June, 1968, Clunet, 1969, p. 101.
} 
Michaud, J., Traducteur-interprète-expert, Textes et réalités, Gaz. Pal. 21-23 March 1993;

Eschylle, J.-F., L'interprétation en matière pénale, RSC, 1992;

Koering-Joulin, R., La notion européenne de „tribunal indépendant et impartial” au sens de l'article 6 de la Convention européenne de sauvegarde des droits de l'homme, RSC 1990 ;

Didier, E., Langues et langage du droit, Wilson / Lafleur Ltée, Montréal, 1990;

Soulier, G., L'égalité de parole, principe de la démocratie et du procès pénal, Le théâtre et le procès, nos. 17-18/1991;

Mauro, J., Au Carrefour des droits et des langues: La langue applicable au contrat, le risqué linguistique, Gaz Pal 1988/1;

Terré, Fr., Brèves notes sur les problèmes de la traduction juridique, Revue internationale de droit comparé, 1986;

Michaud, J., Le traducteur et l'expert, RSC 1985;

Sperduti, G., L'article 6 de la Convention européenne des Droits de l'Homme et les décisions administratives internes affectant des droits de caractère civil, Mélanges Pictet, 1984;

Lasalle, J.-Y., La comparution du prévenu, RSC 1981;

Pergnier, M., Les fondements sociolinguistiques de la traduction, Thesis, Lib. Honoré Champion, 1978;

Malaurie, Ph., Le droit français et la diversité des langues, Journal de droit international, 1965;

Merlin, Répertoire universel et raisonné de jurisprudence, Tom. XV, ed. 5, Bruxelles, 1826. 